\title{
A multibeam bathymetric survey of Bay of Islands, Newfoundland: new evidence of late-glacial and Holocene geological processes
}

\author{
John Shaw ${ }^{1}$, Martin Batterson $^{2}$, Harold Christian ${ }^{3}$, and Robert C. Courtney ${ }^{1}$ \\ ${ }^{I}$ Geological Survey of Canada (Atlantic), Bedford Institute of Oceanography, \\ Dartmouth, NS B2Y 4A2, Canada<shaw@agc.bio.ns.ca> \\ ${ }^{2}$ Geological Survey of Newfoundland and Labrador, Department of Mines and Energy \\ P.O. Box 8700, St. John's, NF AlB 4J6, Canada \\ ${ }^{3}$ Christian Situ Geoscience Inc., 6881 Churchill Drive, Halifax, NS B3L 1E8, Canada
}

Date Received: February 6, 2001

Date Accepted: June 21, 2001

\begin{abstract}
Multibeam bathymetric imagery of Bay of Islands, Newfoundland, is interpreted within the context of late-glacial and post-glacial processes. West of Humber Arm, the fiord floor is irregular and deep. Humber Arm has steep sidewalls and a flat floor. It contains glaciomarine mud, capped by a layer of red mud probably derived from the Deer Lake Basin, which was connected to the ocean ca. $12.2 \mathrm{ka}$. In the early postglacial period, sediments on the fiord sidewalls slid into deep water, forming erosional channels. Depositional lobes, stacked in many areas, overlie glaciomarine sediments in deep water. The glaciomarine and submarine slide sediments are overlain by postglacial mud that is imprinted by elongate, ovoid, and circular fluid-escape trenches, and sedimentary furrows. The natural morphology of the fiord has been modified by anthropogenic activity at Corner Brook. Effects include an apron of bark offshore from the paper mill, dredge spoil, and a sunken vessel at the mouth of Humber River. Large submarine slides, probably triggered by wharf construction at Seal Head, formed deep channels on the fiord sidewalls and overlapping depositional lobes on the fiord floor. They are morphologically similar to the lateglacial slide failures in the fiord.
\end{abstract}

Les images bathymétriques multifaisceaux de Bay of Islands, Terre-Neuve, sont interprétées dans le contexte des processus tardiglaciaires et post-glaciaires. À l'ouest de Humber Arm, le fond du fjord est irrégulier et profond. Humber Arm est doté de parois abruptes et d'un fond plat. Il renferme de la boue glaciomarine recouverte d'une couche de boue rouge provenant probablement du bassin du lac Deer, qui était relié à l'océan il y a environ 12,2 milles d'années avant nos jours. Au début de la période post-glaciaire, les sédiments sur les parois du fjord ont glissé à l'intérieur de l'eau profonde en formant des chenaux d'érosion. Des lobes sédimentaires s'empilant en de nombreux endroits recouvrent les sédiments glaciomarins en eaux profondes. Les sédiments de glissement glaciomarins et sous-marins sont recouverts d'une boue post-glaciaire marquée de tranchées allongées, ovoïdes et circulaires d'évacuation des liquides et de sillons sédimentaires. L'activité anthropique a modifié la morphologie naturelle du fjord à Corner Brook. Les effets de cette activité comprennent un tablier d'écorce au large de la papeterie, des matériaux de dragage et un navire ayant coulé à l'embouchure de la rivière Humber. D'importants éboulements sous-marins, probablement causés par la construction du quai de Seal Head, ont formé des chenaux profonds dans les parois du fjord et des lobes sédimentaires qui se superposent sur le fond du fjord. Ceux-ci sont morphologiquement analogues aux fractures de glissement tardiglaciaires dans le fjord.

Traduit par la rédaction

\section{INTRODUCTION}

The coastline of Newfoundland contains many fiords, but little geological research has been done on them. They are not described in either the standard textbook on fiords (Syvitski $e t$ al. 1987) or in reviews (Syvitski and Shaw 1995). However, the Geological Survey of Canada has surveyed a number of Newfoundland fiords in recent years. Those in Notre Dame Bay were surveyed under the auspices of a program to determine the potential for marine gold placers (Shaw et al. 1999a). Fiords elsewhere have been investigated as part of a program of sea-level research, the principal interest being the presence or absence of submerged early Holocene deltas (Shaw and Forbes 1995). Bay of Islands was initially surveyed in 1994 using seismic and sidescan sonar systems.

A major advance in marine geology in recent years has been the use of multibeam bathymetry systems to map the seascapes of the continental shelf (Courtney and Shaw 2000). Parts of Bay of Islands were mapped in 1996 using a multibeam bathymetry mapping system. The imagery generated from the multibeam data revealed morphologic features identified on the earlier survey, as well as a wealth of previously unmapped features. The imagery derived from the multibeam bathymetry data is the focus of this paper.

\section{STUDY AREA}

Bay of Islands (Fig. 1) is a fiord on the west coast of 


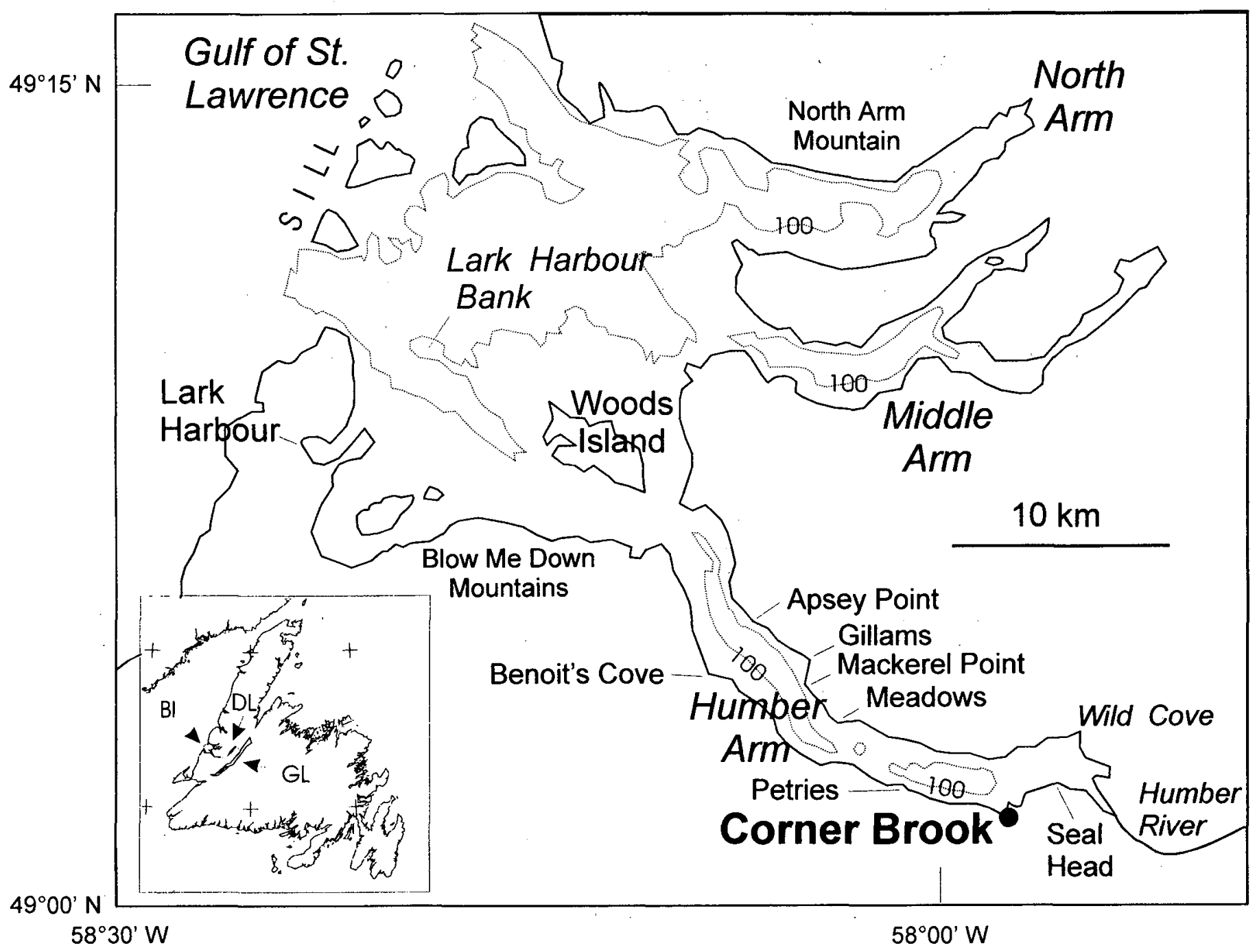

Fig. I. Map of Bay of Islands, with depths in metres. Inset shows location of Bay of Islands (BI), Grand Lake (GL), and Deer Lake (DL).

Newfoundland with several branches, including Humber Arm, the focus of this study. Humber Arm extends to the southeast and connects with the valley of the Humber River, which drains Deer Lake. The mouth of Bay of Islands, partly blocked by a cluster of islands, is an arcuate sill. Northwest of the islands, the sill is commonly shallower than $30 \mathrm{~m}$; west and southwest of the islands it is typically $40 \mathrm{~m}$ deep. The 'sill depth', i.e., the deepest connection with the ocean, is at $46 \mathrm{~m}$. Landward of the sill, the fiord is comprised of basins that reach a maximum depth of $298 \mathrm{~m}$ near Lark Harbour Bank (Fig. 1). Humber Arm is just over $110 \mathrm{~m}$ deep at its mouth, shallows gently towards its head. Off Corner Brook the sea floor rises steeply towards a flat-lying, shallow $(-6 \mathrm{~m})$ shoal at the mouth of Humber River.

The sill is composed of ice-contact sediment (till) and is interpreted by Josenhans et al. (1990) as a submarine moraine marking a major ice margin. Recent research (Shaw et al. 2000) tends to support the hypothesis that a series of comparable submarine moraines around the coast of south and west Newfoundland formed when ice calved across the inner shelf and attained a stable position about $14,000{ }^{14} \mathrm{C}$ yr BP. On the other hand, Grant (1989a) considered that this arcuate margin was the late Wisconsinan ice limit, formed by a piedmont glacier emanating from the Great Northern Peninsula. It is also depicted on the maps of Dyke and Prest (1987) as the 18-14 ka ice limit.

Glaciers retreated from the outer coast before $13.7 \mathrm{ka}$ and were at the head of the bay by $12.7 \mathrm{ka}$ (Grant 1989a, b). Mytilus edulis shells at $+47 \mathrm{~m}$ elevation in delta foresets at Lark Harbour were dated at 12,000 \pm 320 BP (GSC-1462) (Brookes 1974). Hiatella arctica shells in laminated silt at Cox's Cove date a $+49 \mathrm{~m}$ marine limit delta at $12,600 \pm 170 \mathrm{BP}$ (GSC-868), suggesting that ice existed in confined valleys following marine incursion into Bay of Islands (Brookes 1974). Deltaic sediments at the mouth of the Humber River $(+47 \mathrm{~m})$ were interpreted as showing that 'the snout of a valley glacier in the Humber Valley stood near the fiord head when a proglacial delta was being built into the sea at 160 feet $(49 \mathrm{~m})$ (Brookes 1974, p. 18). Grant (1987) reported marine shells dated at $12,700 \pm 300 \mathrm{BP}$ directly inland of this delta.

The marine limit increases from $+50 \mathrm{~m}$ at the entrance to Bay of Islands, to $+75 \mathrm{~m}$ at the head of Humber Arm (Grant 1989b). Relative sea level fell rapidly following deglaciation, reaching present sea level ca. $10 \mathrm{ka}$, and dropping to an early Holocene lowstand of about $-6 \mathrm{~m}$ (at the head of Bay of Islands; see Shaw et al. 1995). Batterson et al. (1993) argued 
that glacial Lake Howley - a proglacial lake in the Grand Lake Basin at about $140 \mathrm{~m}$ above present sea level (Fig. 1) was impounded by ice dam in the Humber River valley. Marine incursion accompanied glacial retreat up the Humber River valley, producing the delta at the mouth of Deer Lake, reaching a maximum elevation of $+45 \mathrm{~m}$, recorded by deltas at the head of Deer Lake. The age of the marine connection is known from a site at +13 m elevation in the Humber River Gorge. The pebbly mud at this site contained barnacle shell fragments (Balanus hameri) and clam shell fragments (Hiatella arctica); the former are dated at $12,220 \pm 90 \mathrm{BP}$ (TO2885) (Batterson et al. 1993).

During the marine phase in Deer Lake Basin, deltas formed at the basin edges and thick successions of finegrained rhythmites blanketed the basin floor (Batterson et al. 1993). Deer Lake was isolated from marine influence in the early Holocene, and now lies at an elevation of $+5 \mathrm{~m}$, drained by the Humber River that enters Bay of Islands at Corner Brook.

\section{ObJECTIVE}

The objective of this paper is to describe the recentlyacquired multibeam imagery, and interpret it within a framework of late Quaternary events in the Bay of Islands region. We focus on three aspects.

1) The large-scale morphology of the fiord and the acoustic and lithologic facies of Quaternary sediments that it contains.

2) The range of meso-scale morphologic features revealed on multibeam imagery, and the processes, including human intervention, that formed them.

3) The question of whether or not there is evidence to corroborate the hypothesis of Batterson et al. (1993) that glacial lake drainage occurred ca. $12.2 \mathrm{ka}$, emptying meltwater into Bay of Islands.

\section{METHODOLOGY}

Three geophysical surveys were conducted in Bay of Islands; the tracks are shown on Fig. 2. In addition, the bay was surveyed using a multibeam bathymetric system. The surveys were as follows:

1) In 1994 surveys were conducted using a $20 \mathrm{~m}$ vessel (CSS Hart) equipped with sidescan-sonar, Seistec high-resolution sub-bottom profiler, Bubble Pulser low-frequency sub-bottom profiler, and a Sunbird CTD (Cruise 94138; Shaw et al. 1995). Cores were collected with a gravity corer, and grab samples
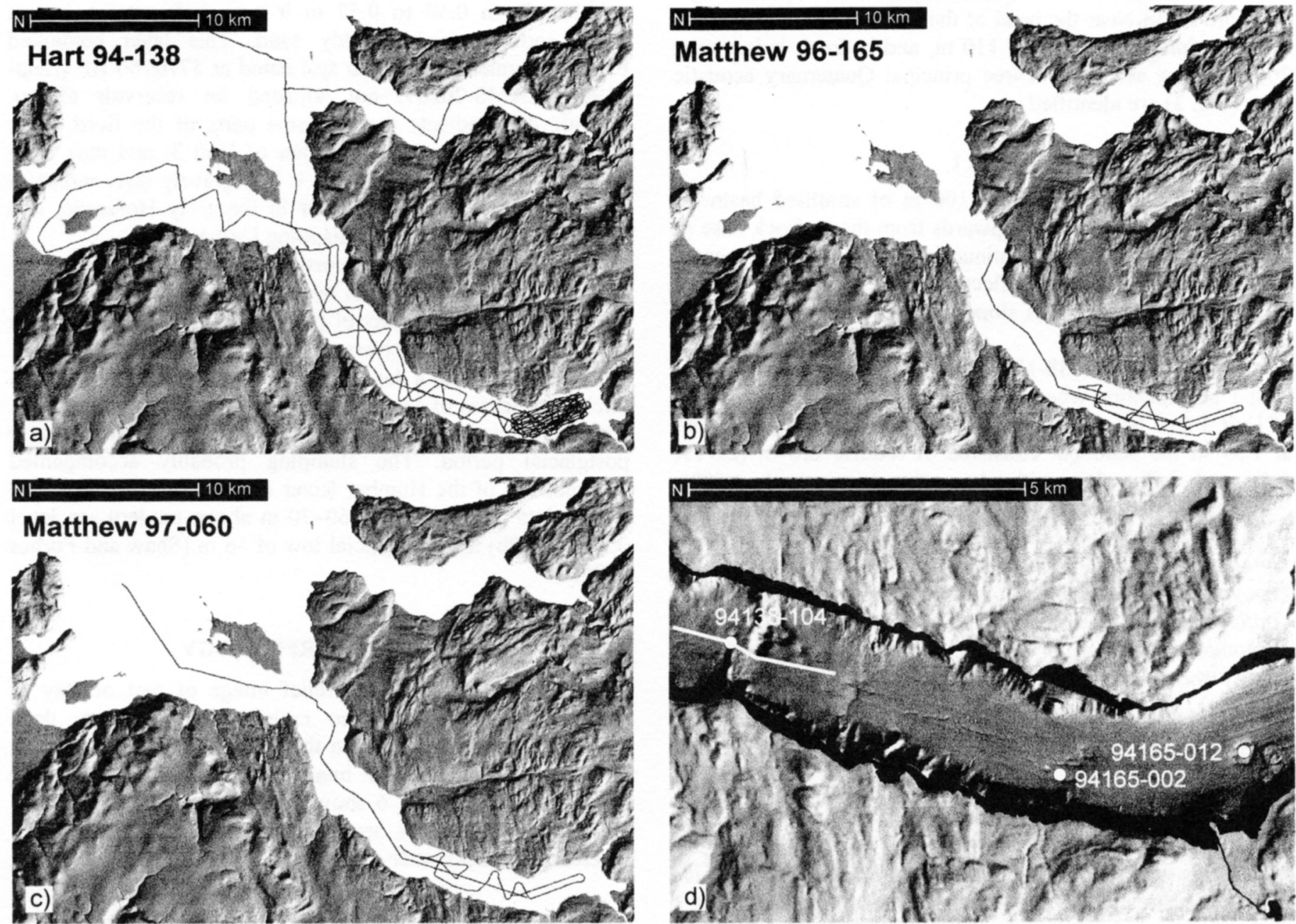

Fig 2. a), b), and c) Tracks of three geophysical surveys in Bay of Islands. d) Locations of Excalibur samples 96165-002 and -012, core 94138104, and the Seistec profile shown at the top of Fig. 4. 
with a medium-sized van Veen grab sampler. Core 94138-104 was analyzed for foraminifera, and shell material was radiocarbon dated.

2) Two surveys were completed in 1996. In the first, parts of Bay of Islands were surveyed with an EM-1000 multibeam bathymetric system. Data were processed to produce shadedrelief images and maps of backscatter. Later in 1996 the multibeam imagery was ground-truthed using CCGS Matthew (Cruise 96165; Shaw et al. 1997) which was equipped with sidescan sonar, a 'sparker' sub-bottom profiling system, and a Seabird CTD (Fig. 2b). We deployed Excalibur, a remotely operated seabed pore fluid sampling system, capable of collecting a $75 \mathrm{cc}$ water/gas sample from depths down to $6 \mathrm{~m}$ below the sea bed. Cores were collected using a gravity corer and grab samples were obtained with a medium-sized van Veen grab sampler.

3) In 1997 a final survey using CCGS Matthew was conducted to collect Seistec high-resolution sub-bottom profiler data along lines that had been surveyed in 1996 with only the sparker system (Cruise 97060; Shaw et al. 1999b).

\section{QUATERNARY SEDIMENTS}

Humber Arm is a ' $V$ ' shaped bedrock trench partly filled with acoustically stratified Quaternary sediments, producing a flat fiord floor. Near the head of the bay, the sediments attain their maximum thickness of $110 \mathrm{~m}$, and bedrock is just over $200 \mathrm{~m}$ below sea level. Three principal Quaternary acoustic units (Fig. 3) are identified.

\section{Unit 1}

This unit comprises up to $100 \mathrm{~m}$ of stratified basin-fill style sediments that extend upwards from the bedrock base of the valley and contain continuous, strong, closely-spaced, parallel, coherent internal reflections (Fig. 3; see also Figs. 9 \& 11). Internal reflections slope upwards towards the mouth of the Humber River.

Gravity core $94138-104$ (Fig. 4) intersected the top of Unit 1 at a location where currents have restricted deposition of Unit 3 (see below). From $0.57 \mathrm{~m}$ to the bottom of the core at $1.59 \mathrm{~m}$ the sediment consisted of reddish brown $(2.5 \mathrm{YR}$ $5 / 4$ ) sandy silty clay, with clay content commonly $>80 \%$. Foraminiferal analysis (Shaw et al. 1995) showed that in Zone 1 (below $0.85 \mathrm{~m}$ ) the sediment was barren of foraminifera. In Zone $2(0.75-0.85 \mathrm{~m})$ the reddish brown clay contained an impoverished assemblage dominated by Cassidulina reniforme and Elphidium excavatum clavata, suggestive of a glaciomarine ice-margin environment with temperature and salinity about $0^{\circ}$ and 25-30\%o respectively. In Zone 3 (0.57$0.75 \mathrm{~m}$ ) Islandiella helenae increases as Cassidulina reniforme decreases. This is indicative of temperature and salinity of $<3^{\circ}$ and 30-33.5\% respectively (Shaw et al. 1995).

Seismic data show that the reddish brown clay observed in core 94138-104 is not typical of Unit 1. The acoustic data suggests a much higher sand and gravel content with depth. By analogy with sediments in other Newfoundland fiords with similar acoustic character (Shaw et al. 1999a), most of Unit 1 likely consists of silty mud with scattered angular grit and dropstones, and was deposited by meltwater plumes and icebergs emanating from Late Wisconsinan ice.

\section{Unit 2}

On acoustic records (Fig. 3; see also Fig. 11) Unit 2 overlies Unit 1 and is acoustically incoherent, light-toned, and occurs as lobes or wedges with irregular upper bounding surfaces. Seaward of Mackerel Point (Fig. 1), multiple lobes of Unit 2 are stacked, completely covering the fiord floor, and giving a maximum thickness of $23 \mathrm{~m}$ (Fig. 3). Between Corner Brook and Meadows (Fig. 1), smaller deposits of Unit 2 fringe the sidewalls on either side of Humber Arm, but do not extend to the middle of the fiord. Unit 2 is interpreted as submarine slide and debris flow deposits resulting from failure of Unit 1 on fiord sidewalls. The source areas are discussed below.

\section{Unit 3}

Unit 3 comprises acoustically weakly-stratified to transparent deposits up to $20 \mathrm{~m}$ thick (Fig 3). The unit is masked by shallow gas in two areas: 1) a patch two kilometres long and one kilometre broad extending along the middle of Humber Arm, from Mackerel Point to Apsey Point; 2) a patch in the deep trough between Woods Island and Blow Me Down (Fig. 1) that extends to the northwest.

Unit 3 was intersected by core $94138-104$ (Fig. 4). From 0 to $0.50 \mathrm{~m}$ thick it consisted of dark greyish brown $(2.5 \mathrm{Y} 4 / 2)$ sandy clayey silt, with worm tubes and scattered angular pebbles. From 0.50 to $0.57 \mathrm{~m}$ it was dark greyish brown poorly-sorted gravely muddy sand. This layer contained bivalve fragments (Macoma sp.) dated at $5770 \pm 60 \mathrm{BP}$ (Beta81980, CAMS-20267; not adjusted for reservoir effect). Seismic data indicate that in some parts of the fiord floor, currents have restricted deposition of Unit 3, and may even have winnowed the top of Unit 1 . The gravely layer indicates that the winnowing was greater in the early Holocene, and since then Unit 3 has been onlapping Unit 1.

Unit 3 is interpreted as mostly postglacial mud, formed by erosion of glacial sediments by waves and currents, and also by input of small amounts of mud and ice-rafted gravel from the Humber and other rivers. At the mouth of Humber River, Unit 3 thickens into a deltaic wedge with numerous landwardthickening lenses of acoustically incoherent sediment (Unit 2), which are interpreted as indicative of slumping in the early postglacial period. The slumping probably accompanied progradation of the Humber River delta as sea level dropped from a late glacial high of 60-70 $\mathrm{m}$ above modern sea level (Grant 1989b) to a postglacial low of $-6 \mathrm{~m}$ (Shaw and Forbes 1995).

\section{SEABED MORPHOLOGY}

Fig. 5 shows a shaded relief image of part of Bay of Islands, produced from the multibeam bathymetry data. Artificial illumination is from the southeast. The surrounding terrain is a shaded-relief image produced from 1:250,000 digital relief data. Fig. 6 shows the backscatter of the same area. High backscatter areas (rock, gravel) are dark toned whereas low backscatter areas (mud) are light toned.

\section{Large-scale morphology}

Within the area surveyed using the multibeam bathymetry system (Fig. 5) the fiord is divisible into two areas 
a)

a)

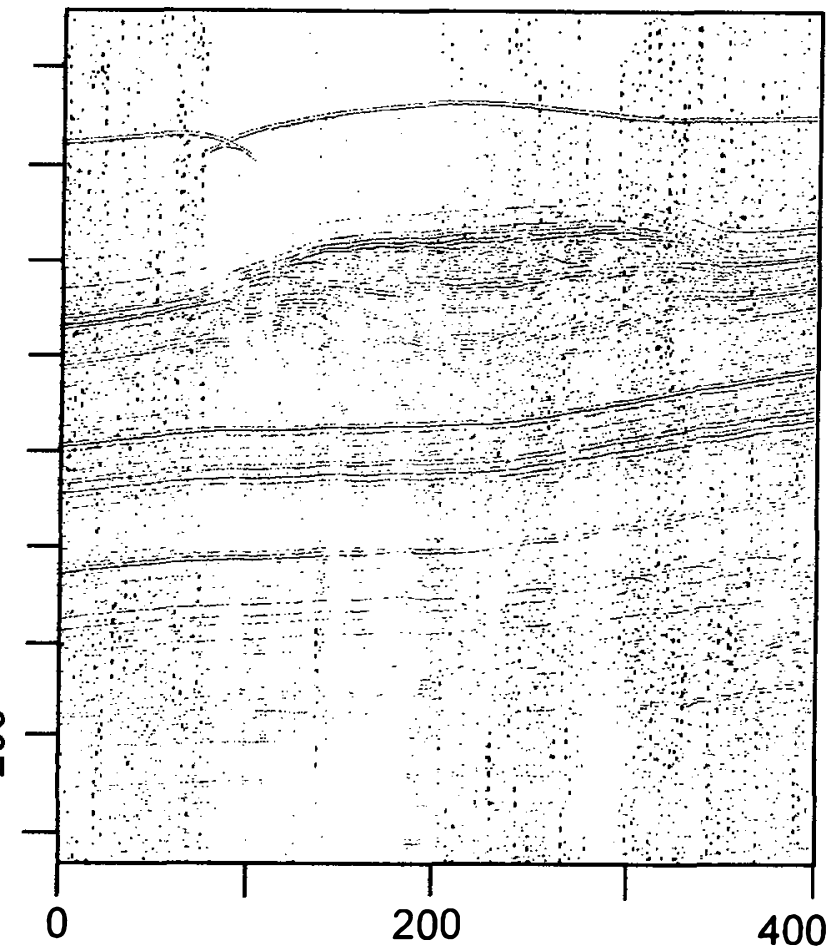

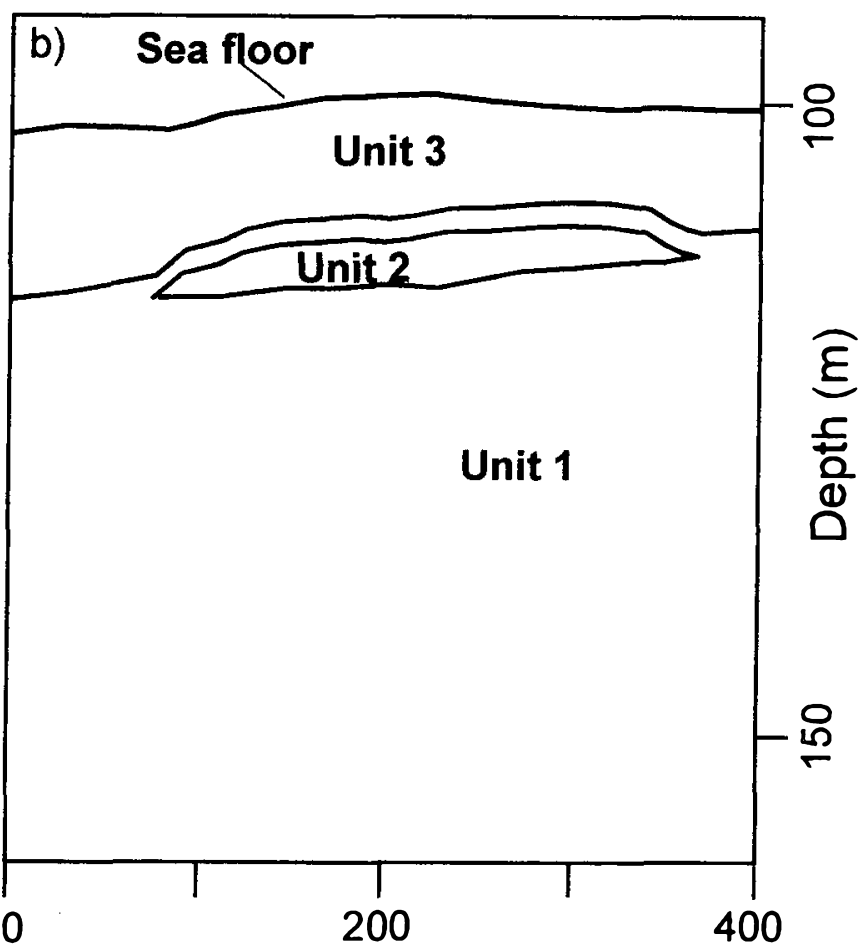

Distance (m)

c)

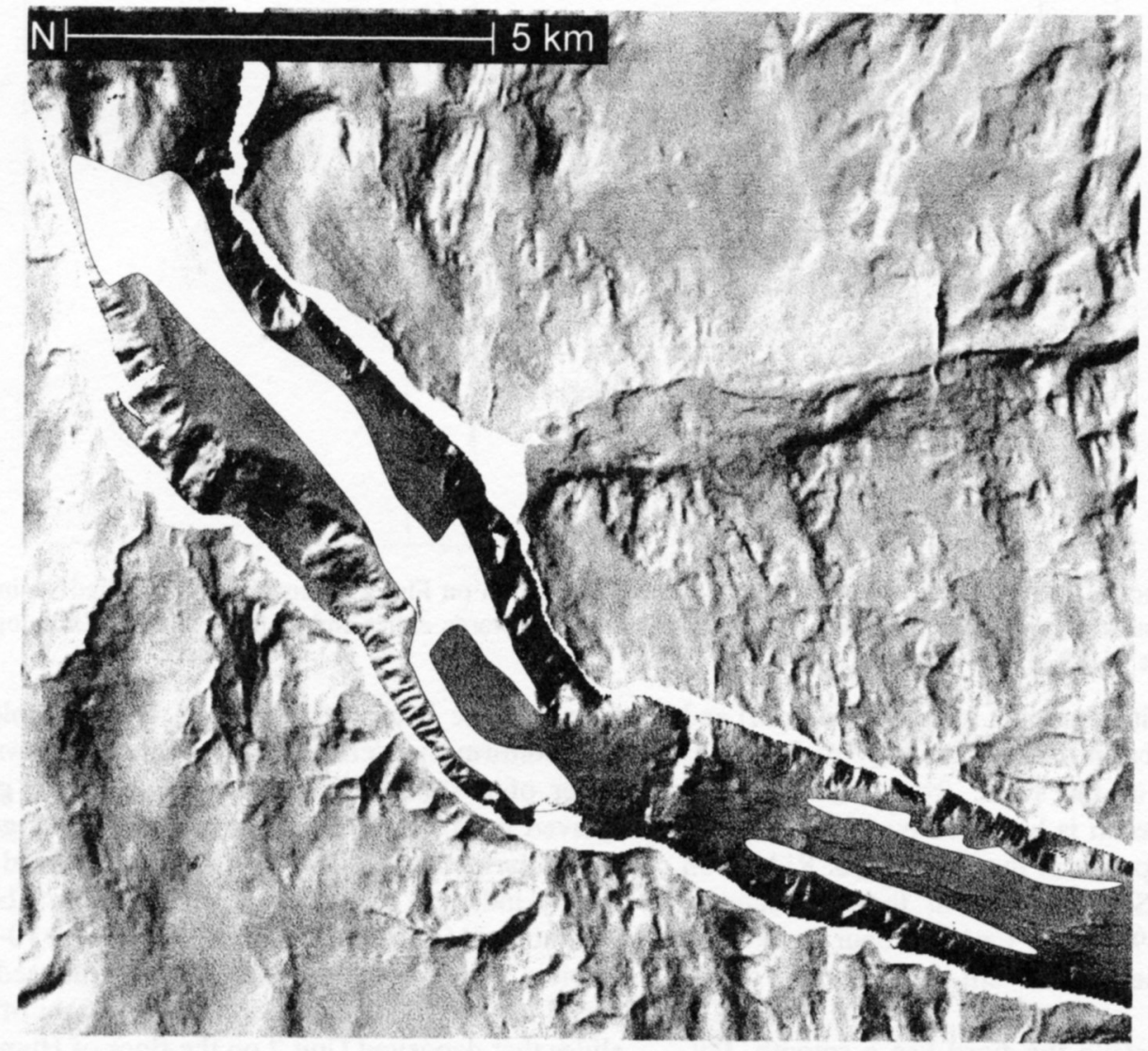

Fig 3. a) and b) Seistec seismic reflection record showing the three principal acoustic facies in Bay of Islands. Location of profile shown on Figure 5. c) Distribution of Unit 2 (light colour) in Humber Arm. 
a)

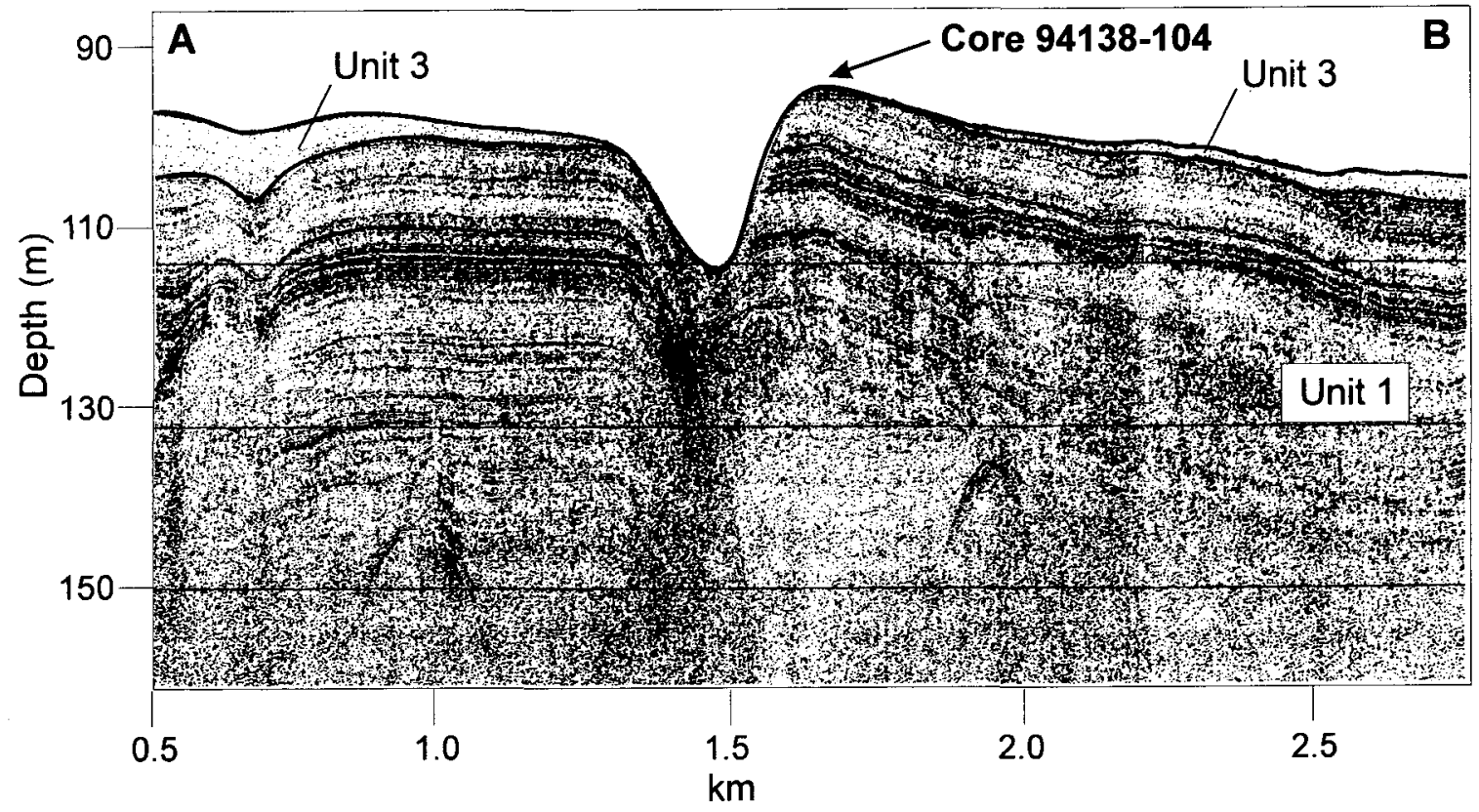

b)
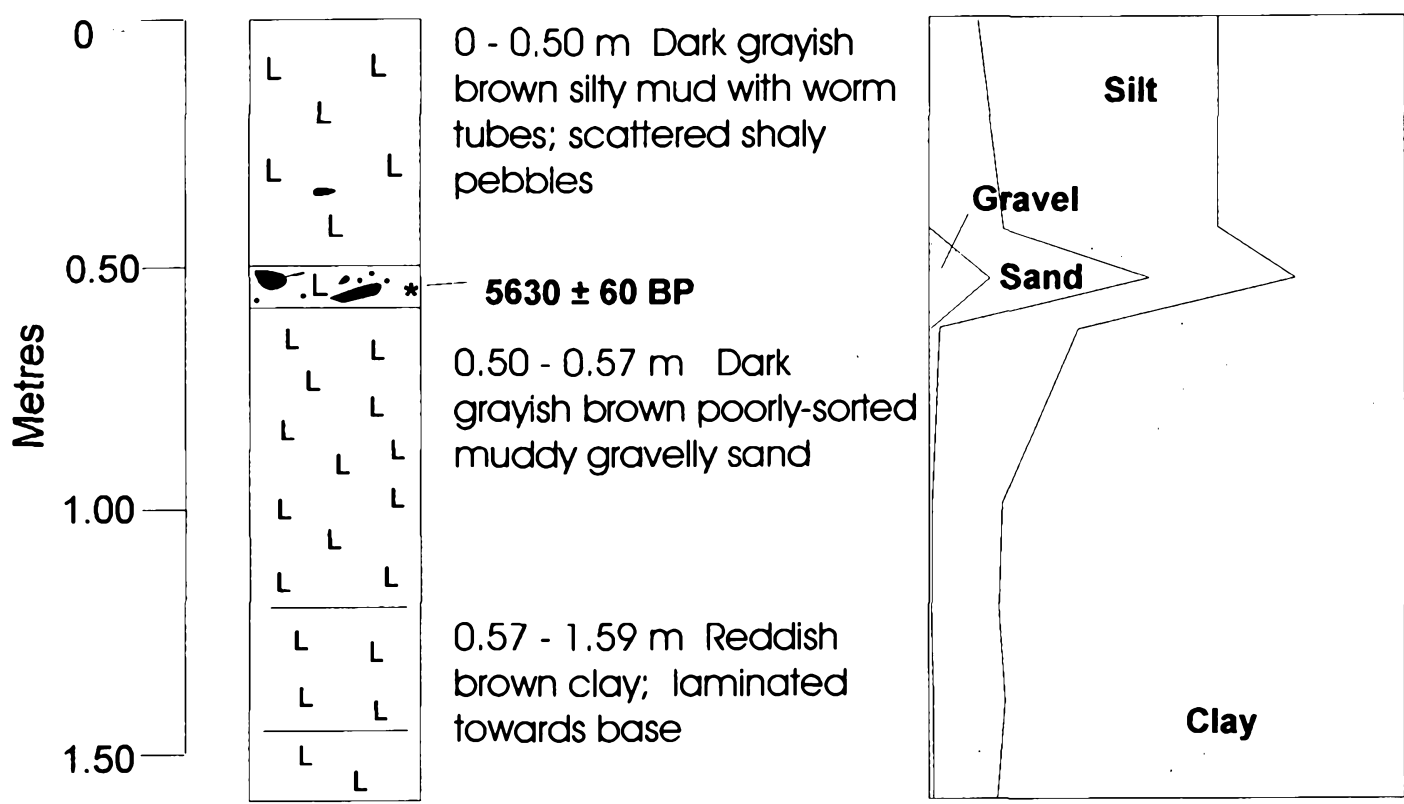

Fig 4. a) Seistec seismic reflection record at site of core 94138-104 (profile location on Fig. 2). Acoustically stratified sediment of Unit 1 is overlain by a veneer of acoustically transparent sediment (Unit 3) that thickens towards either end of the record. b) Lithology, grainsize and foraminiferal zones 1-4 of core 94138-104.

corresponding with Ophiolite Complex rocks (outer fiord) and Late Proterozoic and Cambrian metasedimentary rocks (inner fiord). In the outer part of the fiord, from Woods Island seaward, a deep, narrow trench is bordered by wide, irregular sidewalls that are less steep that in the inner fiord. Ridges on the sidewalls trend NW-SE. The central trench meanders seaward, and deepens to $298 \mathrm{~m}$ off Lark Harbour Bank. The trench shoals steeply to the shallow sill at the mouth of the bay.

Southeast of Woods Island the fiord has a smooth, flat, $1.2 \mathrm{~km}$ wide floor at typical depths of $110 \mathrm{~m}$, has low reflectivity (light tone) on the backscatter image (Fig. 6), indicative of Unit 3. Photographs and grab samples indicate a muddy bottom with brittlestars. The fiord sidewalls (Fig. 7) commonly slope at $20^{\circ}$ and are mostly highly reflective (dark- toned on the backscatter image). Grab samples and seismic data confirm that reflective areas on the sidewalls have a thin cover of postglacial gravely mud (with the gravel probably derived from ice rafting), or a winnowed lag gravel overlying glaciomarine mud. The Humber Arm fiord sidewalls are deeply indented by valleys in many areas. These valleys are commonly $15-25 \mathrm{~m}$ deep off Gillams, and 10-15 m deep off Petries. They are incised into glaciomarine sediments of Unit 1 and are interpreted as the erosional scars of the submarine slides that deposited Unit 2 on the floor of Humber Arm.

\section{Meso-scale fluid-escape features}

Superimposed on the gross morphology we observe a range of natural and anthropogenic features on the floor of 


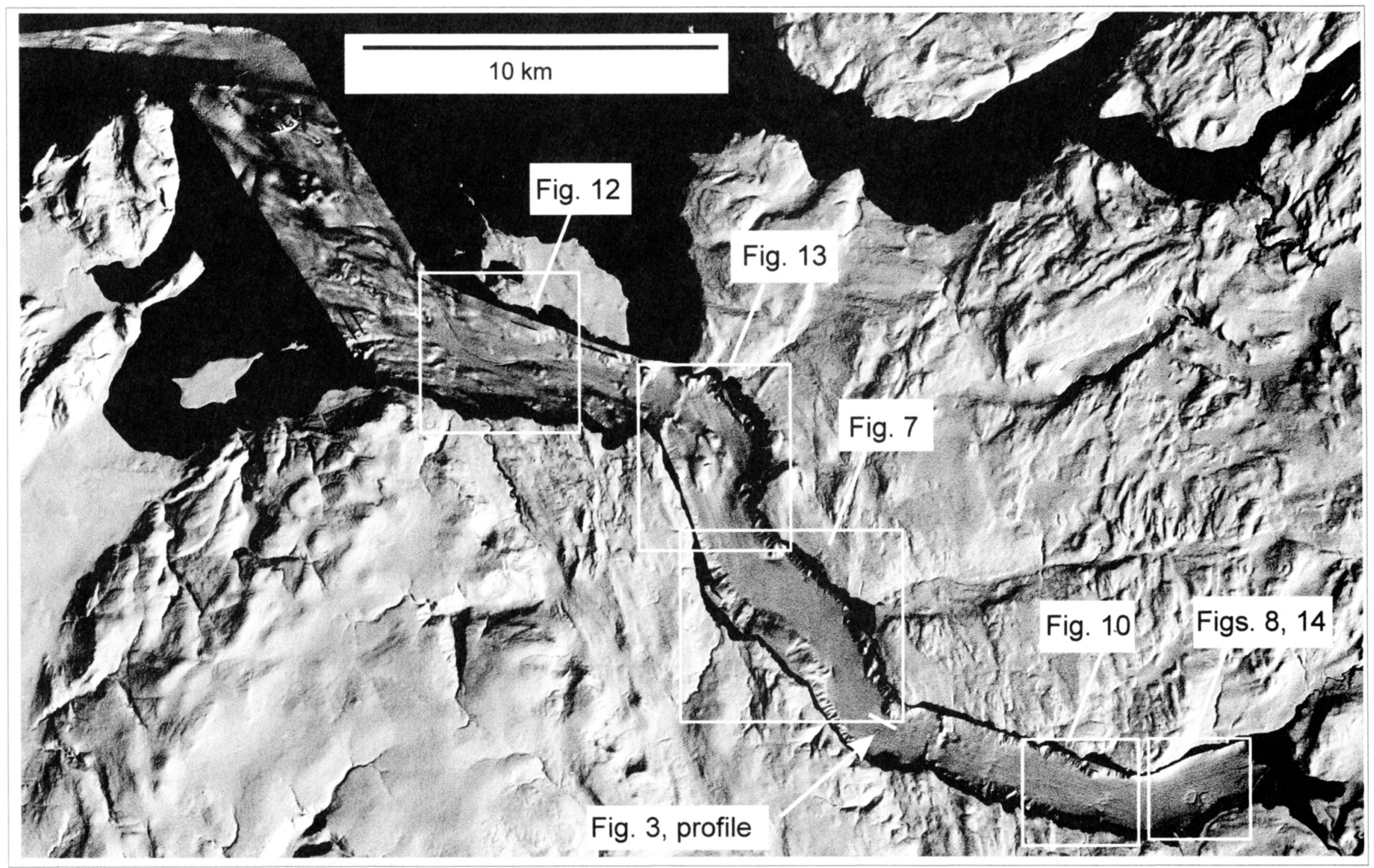

Fig 5. Multibeam bathymetric image of Bay of Islands. Boxes show locations of figures. The white line (arrowed) shows location of the Seistec seismic profile in Figure 3. 


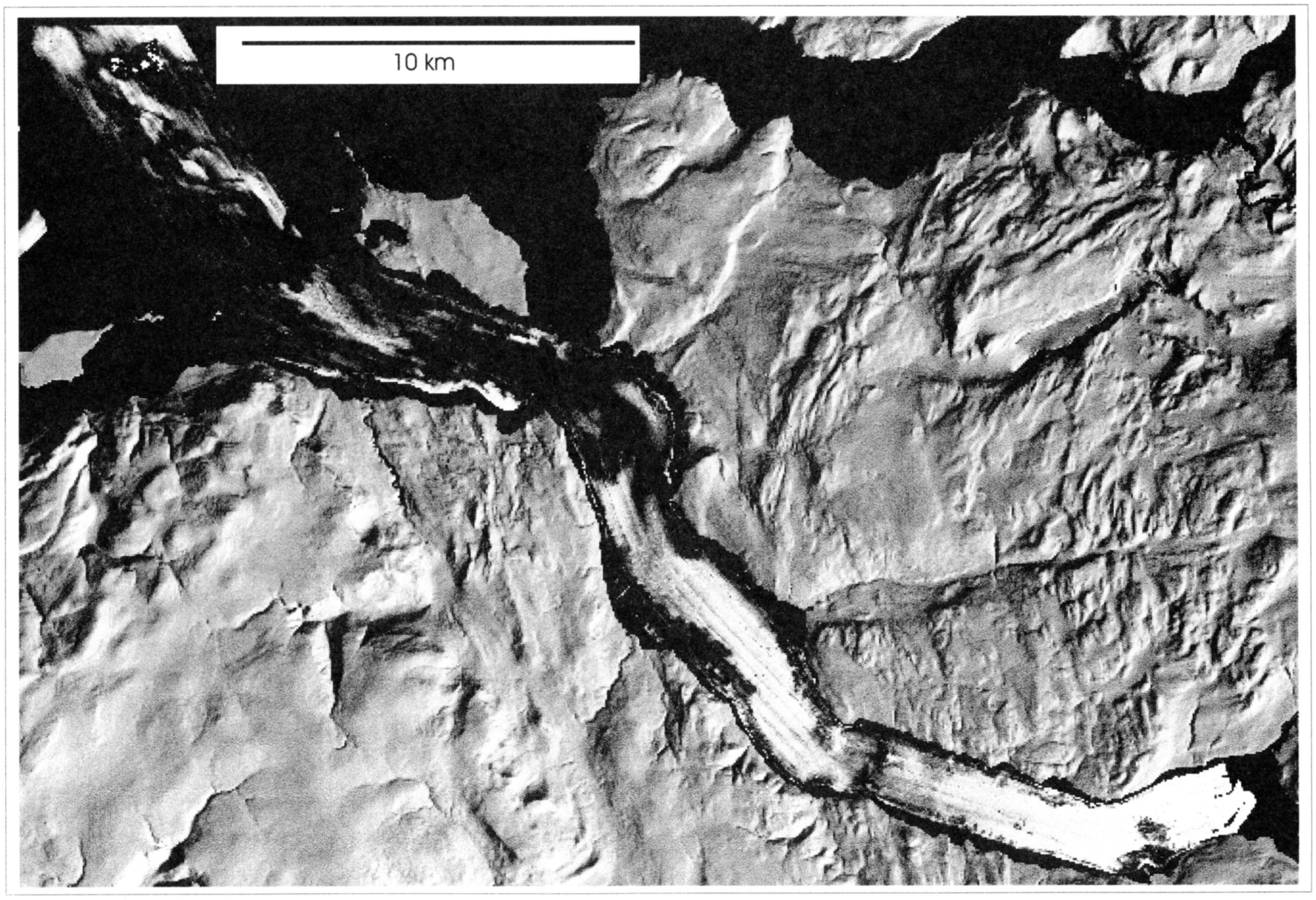

Fig. 6. Backscatter image of Bay of Islands. Dark areas are mud (low backscatter) and light areas are gravel and rock (high backscatter). 




Fig 7. Channeled fiord sidewalls (some indicated by arrows).

Bay of Islands. The first group consists of narrow trenches near the head of the fiord, including an oval $(320 \times 210 \mathrm{~m})$ trench $3 \mathrm{~m}$ deep and $70 \mathrm{~m}$ wide, located at a depth of $95 \mathrm{~m}$ (A on Fig. 8). An inverted conical zone of disrupted internal reflections occurs below the trench and extends downwards through the thick $(110 \mathrm{~m})$ Quaternary sediments towards bedrock (Fig. 9). A small zone of acoustic masking occurs 19 $\mathrm{m}$ below the centre of the trench (not evident on the lowresolution seismic reflection data of Fig. 9). Excalibur sample 012 revealed that methane gas existed within the sediment pore water, suggesting that the masking is due to free gas.

Just west of Corner Brook, trenches occur on the fiord floor at a depth of about $100 \mathrm{~m}$ (Fig. 10, A-D). They are 2-6 $m$ deep, and include both linear and oval elements; one trench has an irregular, 'knotted' appearance (D on Fig. 10). Subbottom profiler data (Fig. 11) show that the acoustic signature of the trenches extends to $90 \mathrm{~m}$ below the seabed, in the form of down-curving internal reflections within Unit 1 . One of the oval trenches had acoustic masking $10 \mathrm{~m}$ below the seabed, and a linear trench had what appears to be gas venting at the sea floor. Excalibur pore water sample 002 (location shown on Fig. 2) from this area contained high amounts of methane (Shaw et al. 1997).

The trenches are interpreted as fluid escape features, formed by venting of gas from either deep within the Quaternary sediments, or from the underlying bedrock. Syvitski (1992) reported seabed depressions in Baie des Chaleurs, which are 0.3 to $2 \mathrm{~m}$ deep, 3 to $15 \mathrm{~m}$ wide, and several kilometres long, caused by gas-escape. The features were alongside major faults. The gas appeared to emanate from a point source, travel horizontally (along bedding planes) in the postglacial sediment, before moving vertically to the surface. The extension of downward curving reflections in the Quaternary sediments in Bay of Islands is suggestive of a bedrock source for the gas.

\section{Meso-scale current flow features}

Trenches in soft sediment off Woods Island, in water depths of 90-100 m, are $70 \mathrm{~m}$ wide and up to $8 \mathrm{~m}$ deeper than the surrounding seabed (A on Fig. 12). Unlike the trenches in the inner bay (Humber Arm), they are smoothly curvilinear, suggesting that currents may play a role in their formation. They are interpreted as sedimentary furrows of type 2c according to the classification of Flood (1981). The furrows are surrounded by acoustic masking. At the edge of the masked area, reflections in the water column observed on both the seismic reflections system and the ship's sounder were interpreted as escaping gas (Shaw et al. 1999b). Excalibur data showed extremely high pore pressures in this area also, perhaps due to migrating gas in the substrate (Shaw et al. 1997). We surmise, therefore, that formation of furrows was triggered by gas venting.

The major current-formed feature in Bay of Islands is a large curvilinear trough in outer Humber Arm (Fig. 13). Along the trough only up to three metres of postglacial mud (Unit 3) overlies glaciomarine sediments (Unit 1). This trough is highly reflective (dark toned on the backscatter image), and grab samples and bottom photographs show the sea floor is mud 


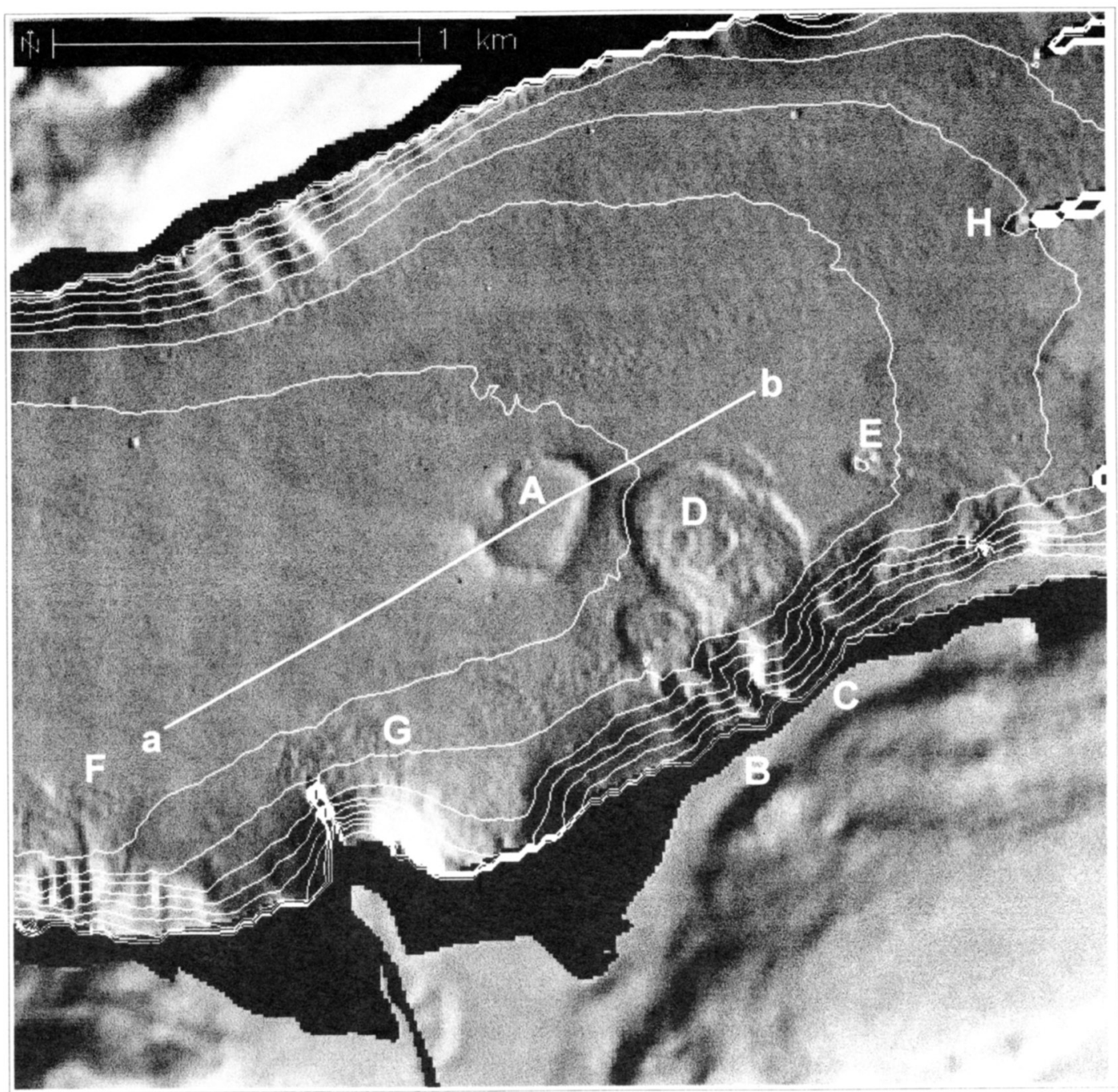

Fig. 8. Multibeam image of the seabed off Corner Brook, showing oval fluid escape structure (A), submarine slide scars (B,C), several superimposed depositional lobes (D), small 'outrunner' slide block with associated slide scar (E), small submarine slide off Crow Head (F), mound of bark off the paper mill $(\mathrm{G})$, and a sunken barge $(\mathrm{H})$. The white line $(\mathrm{a}-\mathrm{b})$ shows location of seismic profile in Fig. 9.

with high gravel content; most clasts have anemones attached. By contrast, mud is banked on either side of the trough; it has low reflectivity (light tone on the backscatter image), and contains only a few gravel clasts. The phenomenon is likely caused by currents of undetermined intensity and frequency, influenced by the Coriolis force, that inhibit sedimentation in the postglacial period. Similar scoured areas and banks have been documented in the fiords of Notre Dame Bay (Shaw et al. 1999a), where gravity corers can easily penetrate surface lags in scoured areas to reach 11,000 year old sediments (for comparison with banked deposits in a Labrador fiord see Barrie and Piper 1982).

\section{Features formed by human activities}

\section{Submarine slides}

Fill dumped on top of the thin glaciomarine mud on the fiord sidewalls triggered at least three submarine slides (Fig. 8) on slopes of $20^{\circ}$ off Seal Head (Fig. 1) in the early 1990s. On the fiord sidewall the slides eroded two channels $18 \mathrm{~m}$ and $30 \mathrm{~m}$ deep (Fig. 8, $\mathrm{B}$ and $\mathrm{C}$ respectively). In the adjacent fiord basin they deposited overlapping lobes (Fig. 8, D) of acoustically incoherent sediment with a combined thickness of $4 \mathrm{~m}$. Areas along the rim of the slide toe are slightly higher in elevation than areas to the rear. A smaller slide (E on Fig. 8) has an arcuate chute and berm, formed by an outrunner block (Syvitski et al. 1987) that veered to the left to flow downslope. Lesser slides are observed on the imagery, including one off Crow Hill ( $\mathrm{F}$ on Fig. 8) that may have been triggered by dumping of soil for road building. A similar slide is observed off Blow me Down Mountain, where rock talus has slid to a depth of $50 \mathrm{~m}$ just offshore from the coastal highway.

\section{Wood-chip deposits}

Low backscatter values delineate an area of bark and wood chips on the sea floor (A on Fig. 14; G on Fig. 8) that thicken and shallow towards the paper mill at Corner Brook. The wood-chip layer contains high amounts of gas, probably methane. Bubbles reaching the sea surface were observed during surveys, and there are local reports of the same phenomenon. Core 94138-65, collected from the bark layer (core location shown on Fig. 14), was about a metre long upon 


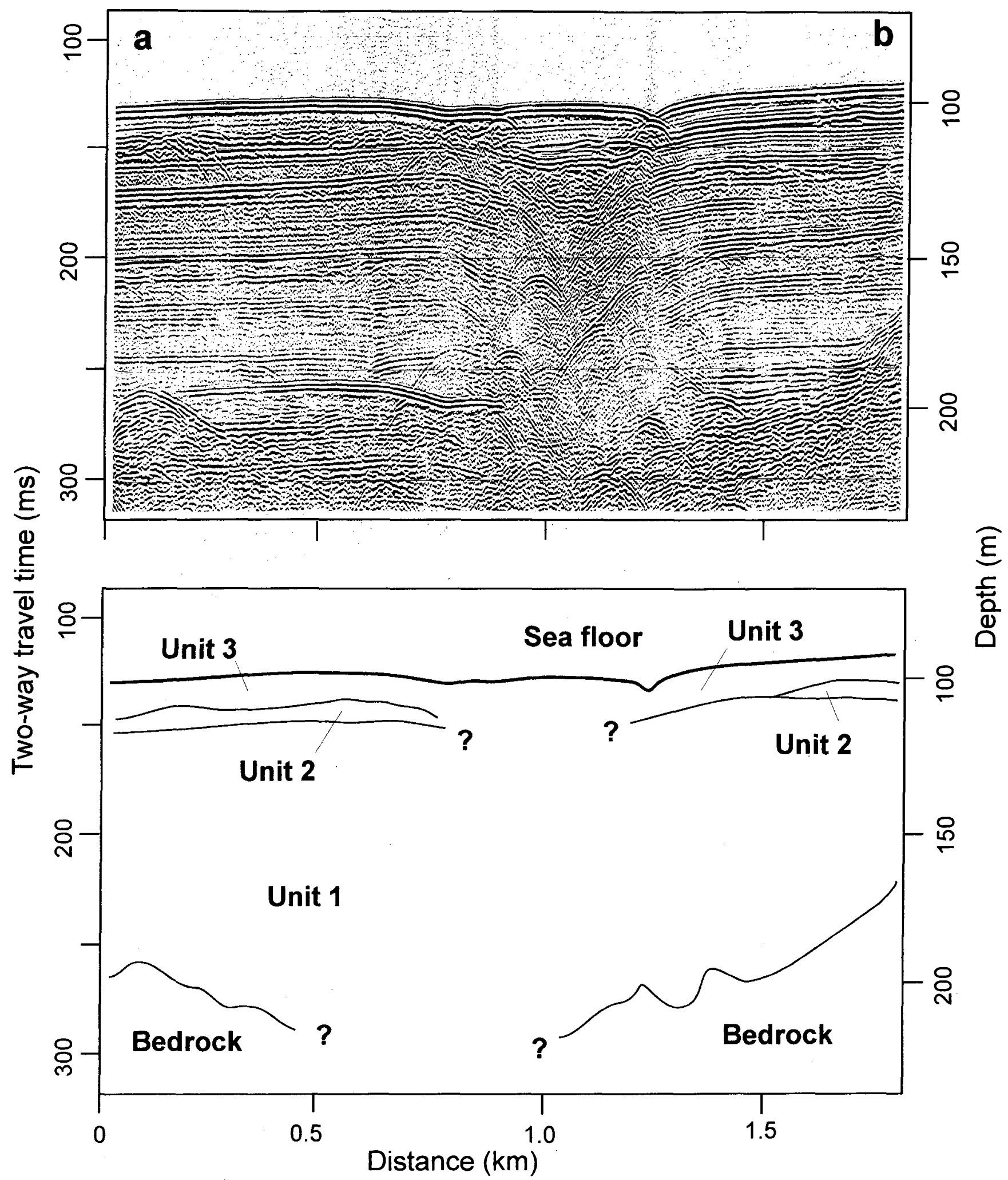

Fig. 9. Sparker seismic reflection data and interpretation along a line intersecting the oval-shaped trench on the sea floor off Corner Brook. Profile location shown on Fig. 8.

recovery but shrank to $0.43 \mathrm{~m}$ when gas escaped and water separated out. The sediment had a strong smell of hydrogen sulphide. The lack of penetration by the sub-bottom profiler system is attributed to the presence of gas in the bark layer.

\section{Other debris}

A $70 \mathrm{~m}$ long vessel in a water depth of $73 \mathrm{~m}$ off Humber River appears as a $5 \mathrm{~m}$ high mound on multibeam imagery (Fig. 8, H), with high backscatter (Fig. 14, B). It was mapped using sidescan sonar (Fig. 15, top) and investigated by the Pisces submersible deployed from HMCS Cormorant in 


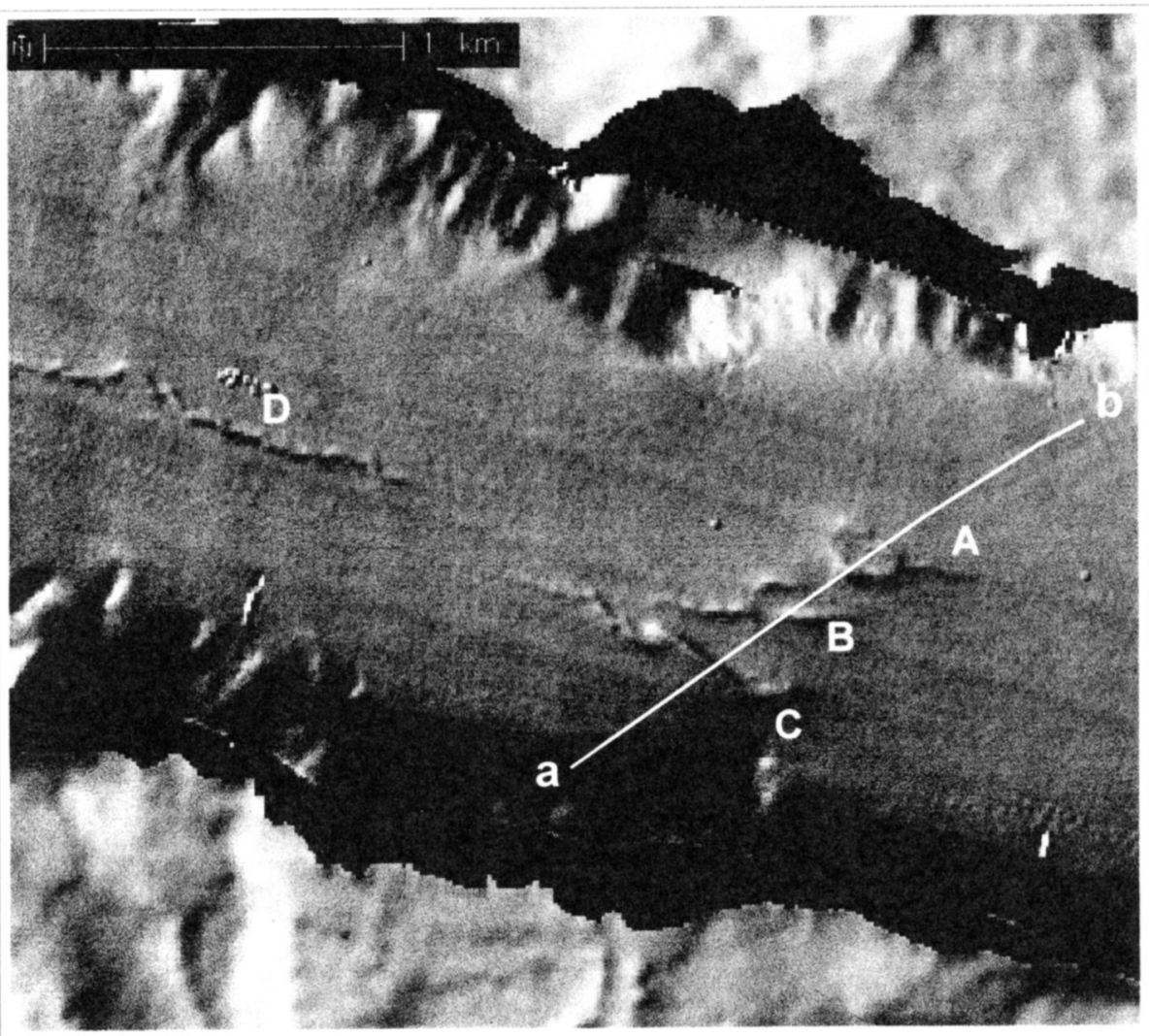

Fig. 10. Fluid escape trenches (A-D) in Humber Arm and location of seismic profile given in Fig. 11 (a-b).

October 1995. Observations and drawings (Fig. 15, bottom) made by $\mathrm{G}$. Cameron suggest that the wreck is a sunken barge.

\section{Dredge spoil}

Irregular areas of high backscatter in the middle of the bay (C on Fig. 14) that are similar to the bark zone in backscatter intensity are believed to be spoil derived from dredging at Corner Brook to facilitate docking of cruise ships at the wharf. The spoil is also visible on sidescan sonar records but not on the multibeam image (Fig. 8).

\section{DiscuSSION}

\section{Deposition of red clay in Bay of Islands}

The following deductions can be made concerning the red clay in core 94138-104: 1) the coloration suggests a Carboniferous redbed source, the most proximal being the Deer Lake Basin; 2) foraminifera analysis indicates reduced salinity; 3 ) the position of the red unit at the top of the glaciomarine sequence shows that it was deposited immediately following deglaciation but before the deposition of Unit 3; and 4) the lack of clasts (dropstones) suggests a non-glacial source. Further confirmation of a local source for red fine-grained sediments is provided by the presence of thick deposits of sandy silty red clay in bluffs at Wild Cove, where Ricketts (1987) described a deposit that is $1.5 \mathrm{~km}$ long, $1 \mathrm{~km}$ wide, and had an estimated thickness of $16 \mathrm{~m}$.

The Deer Lake Basin became connected to Humber Arm ca. 12,200 BP (Batterson et al. 1993). Catastrophic drainage from glacial Lake Howley would have introduced large quantities of meltwater in the Humber River valley (Batterson 1999). However, the high-level glacial lake was short-lived, related lacustrine sediments are scarce (Batterson et al. 1993), and a $50 \mathrm{~km}$ arm of the sea would likely act as a sediment trap for suspended sediment. It is therefore considered unlikely that discharge from glacial Lake Howley would have deposited a clay unit in excess of $1 \mathrm{~m}$ thick in the Humber Arm.

However, during the early marine phase, deltas were built on the margins of the lake, to an elevation of $+45 \mathrm{~m}$. The delta sediments have rare dropstones, suggesting that the ice was not in contact with the sea at the basin margin (Batterson et al. 1993). A compilation by the first author of isobase maps (based on published sea-level data for Atlantic Canada) shows relative sea level rapidly dropped from $+45 \mathrm{~m}$, reached $+5 \mathrm{~m}$ (the level of the modern lake) by ca. $10.5 \mathrm{ka}$, and reached modern sea level by ca. $10 \mathrm{ka}$.

Thus, an alternative argument for the deposition of the red clay bed is that falling sea level re-mobilized the 'thick successions of fine-grained rhythmites' (Batterson et al. 1993) on the floor of Deer Lake Basin, and continued to do so until the connection to the ocean was severed, and modern lake conditions became established, sometime after ca. $10.5 \mathrm{ka}$ This could produce the red muds sampled by core 94138-104 and the red muds at Wild Cove (Ricketts 1987). Precise dating control is necessary to confirm this hypothesis.

\section{Sidewall slumping}

Fiords are prone to a variety of slope failures that are 


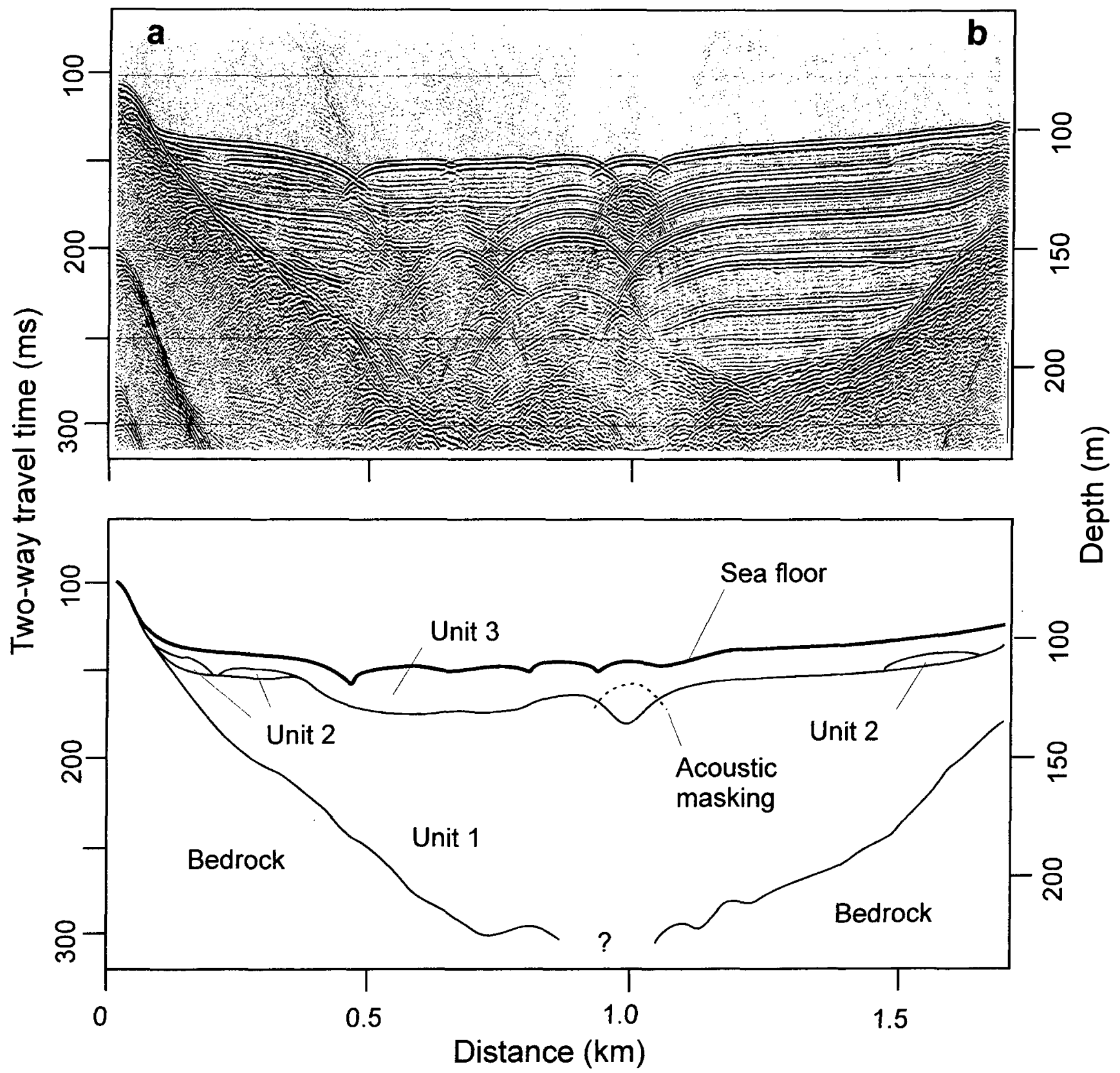

Fig. 11. Sparker seismic reflection profile and interpretation across furrows on the floor of the inner fiord. Profile location shown on Fig. 10.

controlled by four factors: 1) topography; 2) supply of material; 3) sediment physical properties; and 4) releasing mechanism (Syvitski and Shaw 1995). Here, the sidewall gullies are the sources of the mounds and stacked lenses of Unit 3 that underlie postglacial mud on the fiord floor. The submarine slides occurred in a relatively narrow time frame, after retreat of ice to the head of the fiord and deposition of Unit 1 , and before deposition of Unit 3 . This suggests that period of failure was in lateglacial to early postglacial period. Several release mechanisms are considered. Published isobase maps (Grant 1989b), and work in progress by the first author, show that relative sea level dropped nearly $70 \mathrm{~m}$ in 3,000 years (13-10 ka). It is possible that as glaciomarine muds were subaerially exposed they increased the load on mud below water level, and initiated slides that extended into deep water.

A second possible explanation is release of crustal stress.
The greatest stress differentials are at ice sheet margins, and in the lateglacial period the ice margin was retreating inland from its maximum limit. Sub-glacial stored stress is released at this time, producing seismic shaking and possibly faulting (cf. Bøe et al. 2000; Hicks et al. 2000). Large-scale bedrock slumps occur farther north, in the Bonne Bay area, and are believed to be caused by residual tectonic stress following deglaciation (Grant 1987).

\section{Current-formed features}

We have described two seascape elements (sedimentary furrow in the outer fiord, and curvilinear trough in the inner fiord) that are indicative of current activity on the floor of the fiord. However, it is hard to translate this evidence into quantitative terms. It may be that the currents occur when the 


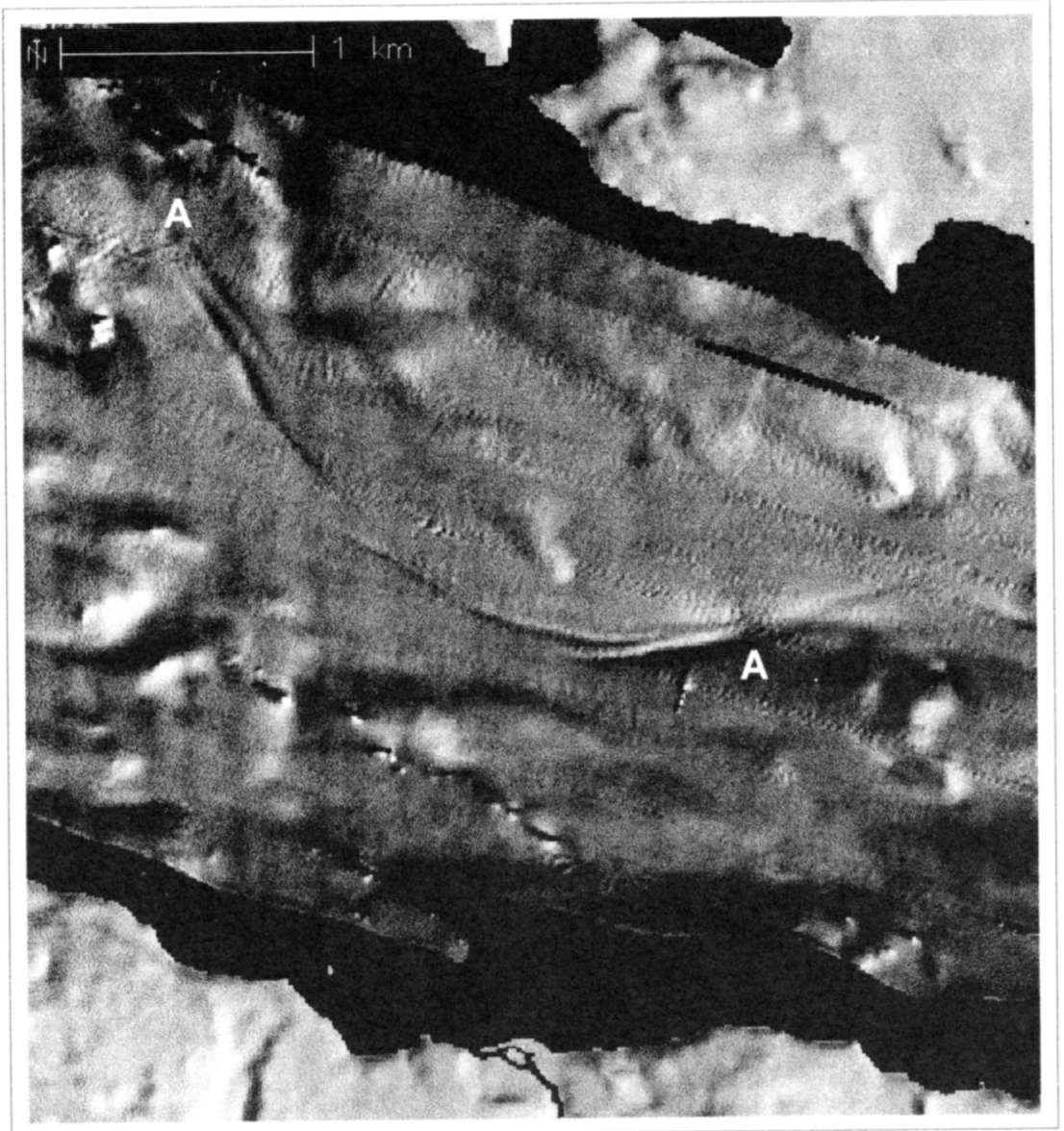

Fig. 12. Sedimentary furrows in the outer fiord. Water depth along the furrows is about $100 \mathrm{~m}$. See text for discussion.
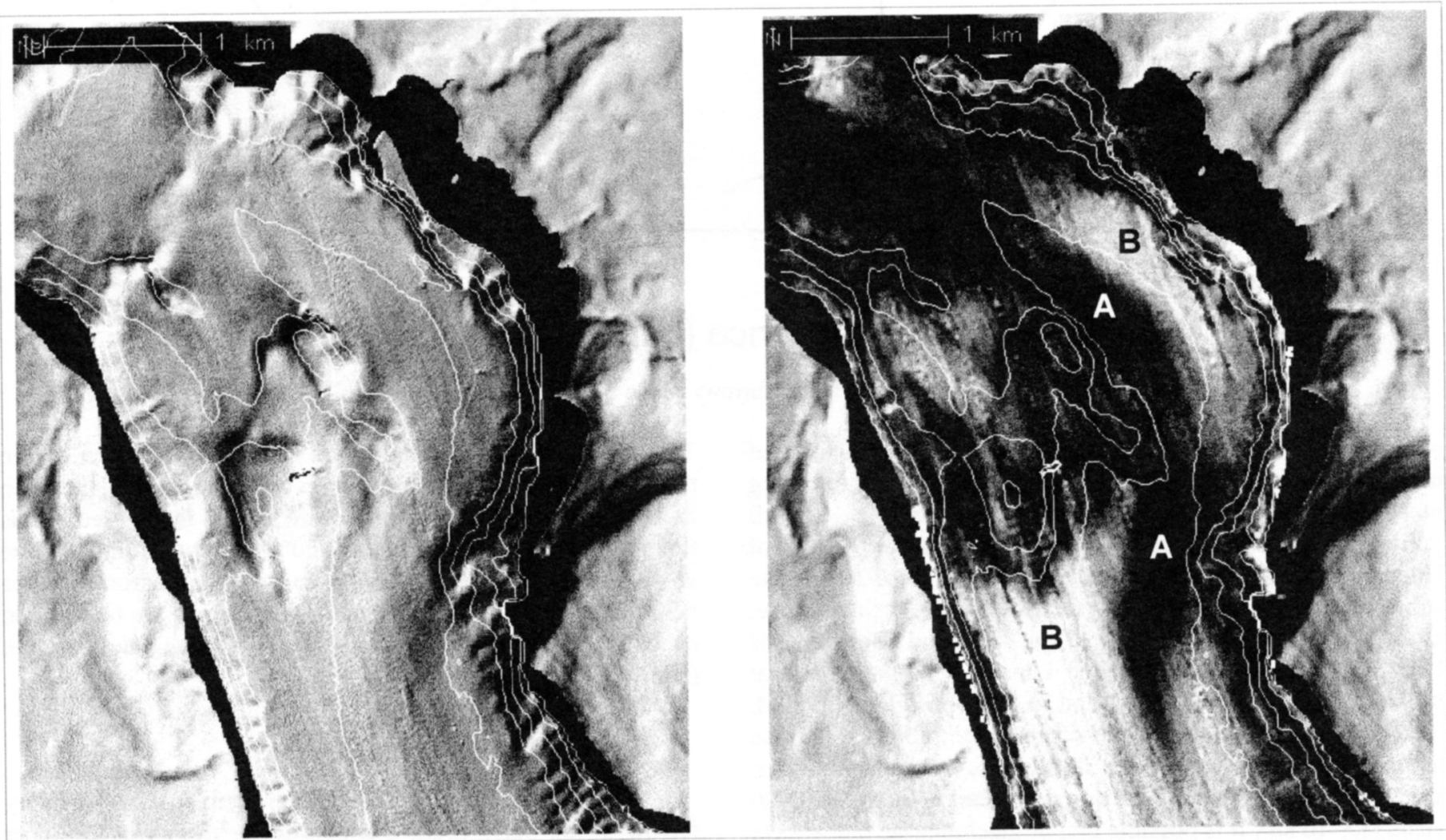

Fig. 13. Curvilinear area of low sedimentation at the entrance to Humber Arm. Image at left is the multibeam image with contours at $20 \mathrm{~m}$ intervals, while image at right shows backscatter. The curvilinear area (A) has low sedimentation rates, and the sea floor is gravelly mud. The surrounding banks of mud (B) have low gravel content. 


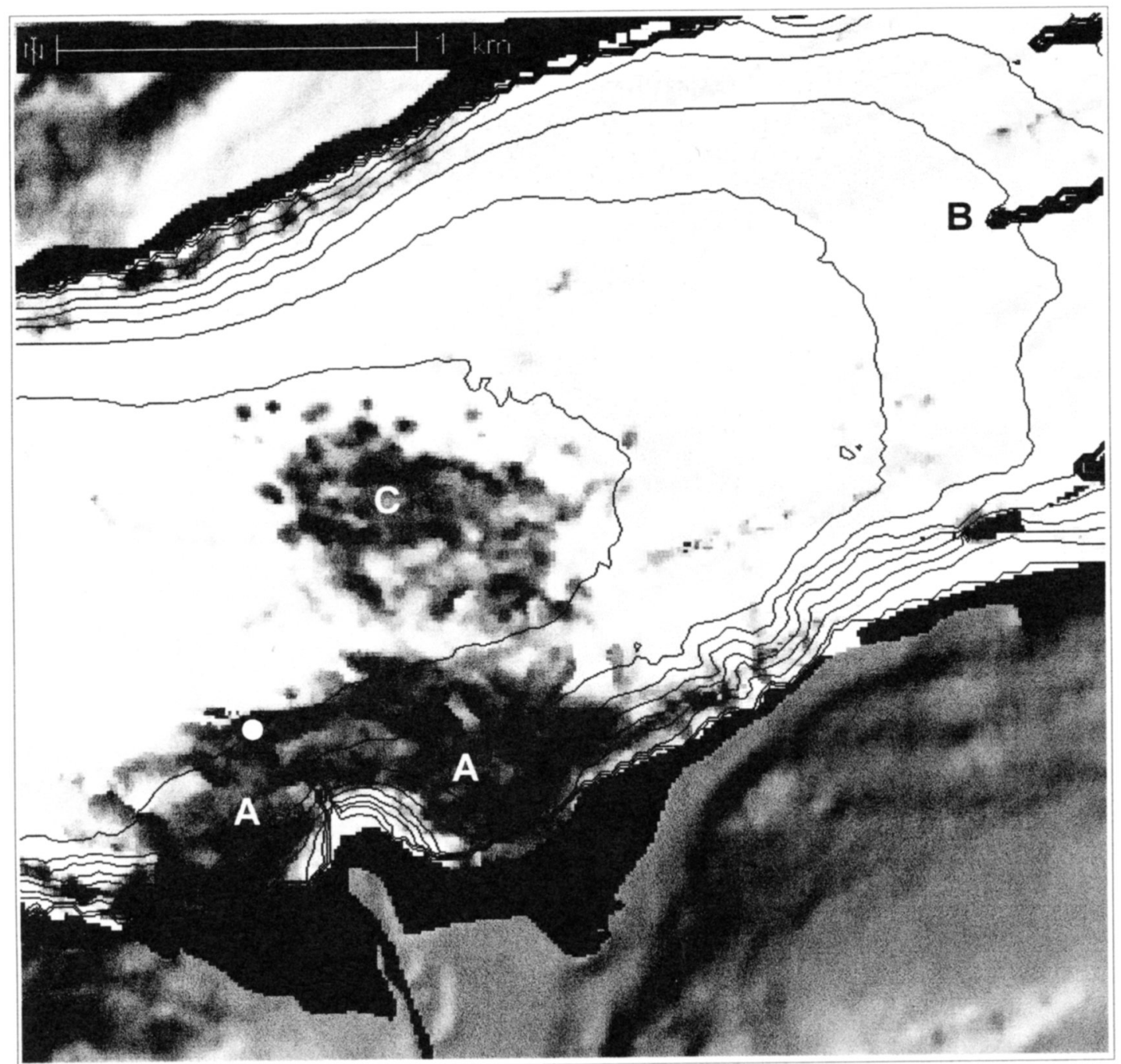

Fig. 14. Backscatter image of the area shown in Fig. 8 (dark areas have high backscatter) showing bark (A), a sunken barge (B) and dredge spoil (C). The white dot indicates the location of core 94138-65.

water in the fiord is overturned by water from outside (see Syvitski et al. 1989). CTD profiles in October 1994 showed warm water down to sill depth $(30-40 \mathrm{~m})$ with cold $\left(-1^{\circ} \mathrm{C}\right)$ water extending to the floor of the fiord. Overturning could occur when Gulf water at sill depth is colder than the base of the warm layer. This probably occurs in spring.

\section{Human impacts}

Human activities have had considerable impact in Bay of Islands. The steep sidewalls are susceptible to submarine slope failure. We suspect that loading of spoil during wharf extension may have triggered the slide off Seal Head. Although the mechanism may have differed, the slide morphology - a deep channel leading to a slide toe on the flat fiord floor - is identical to the morphology of the lateglacial slides whose slide chutes are still apparent, but whose depositional lobes are buried. The small slides observed elsewhere are different, in that they consist of aprons of terrestrial debris that has slid into deep water.

The multibeam bathymetry system is an excellent sensor to delineate the extent of the bark previously dumped from the paper mill (currently bark is stored on land). The lack of penetration by seismic systems suggests that methane gas is being created within the bark deposit. The extent and thickness of dredge spoil are small compared with those found off several other Atlantic Canadian ports where dredging is more frequent (e.g., Saint John; Parrott et al. 2000). Finally, the identity of the sunken vessel remains unknown. A sketch by $\mathrm{G}$. Cameron based on observations from a submersible (Fig. 15, bottom) suggests that it is a barge. Local residents have described a barge that was scuttled or was grounded on Humber River delta, and later slipped into deep water.

\section{Conclusions}

1) Humber Arm, Bay of Islands has a gross morphology similar to that of other Newfoundland fiords - steep sidewalls, a ' $V$ ' shaped bedrock trough containing stratified glaciomarine sediments.

2) The red clay at the top of the glaciomarine sequence is consistent with deposition from a source in Deer lake Basin, perhaps re-mobilized sediments originally deposited during a +45 marine incursion into the basin ca. 12,200 BP. 
a)

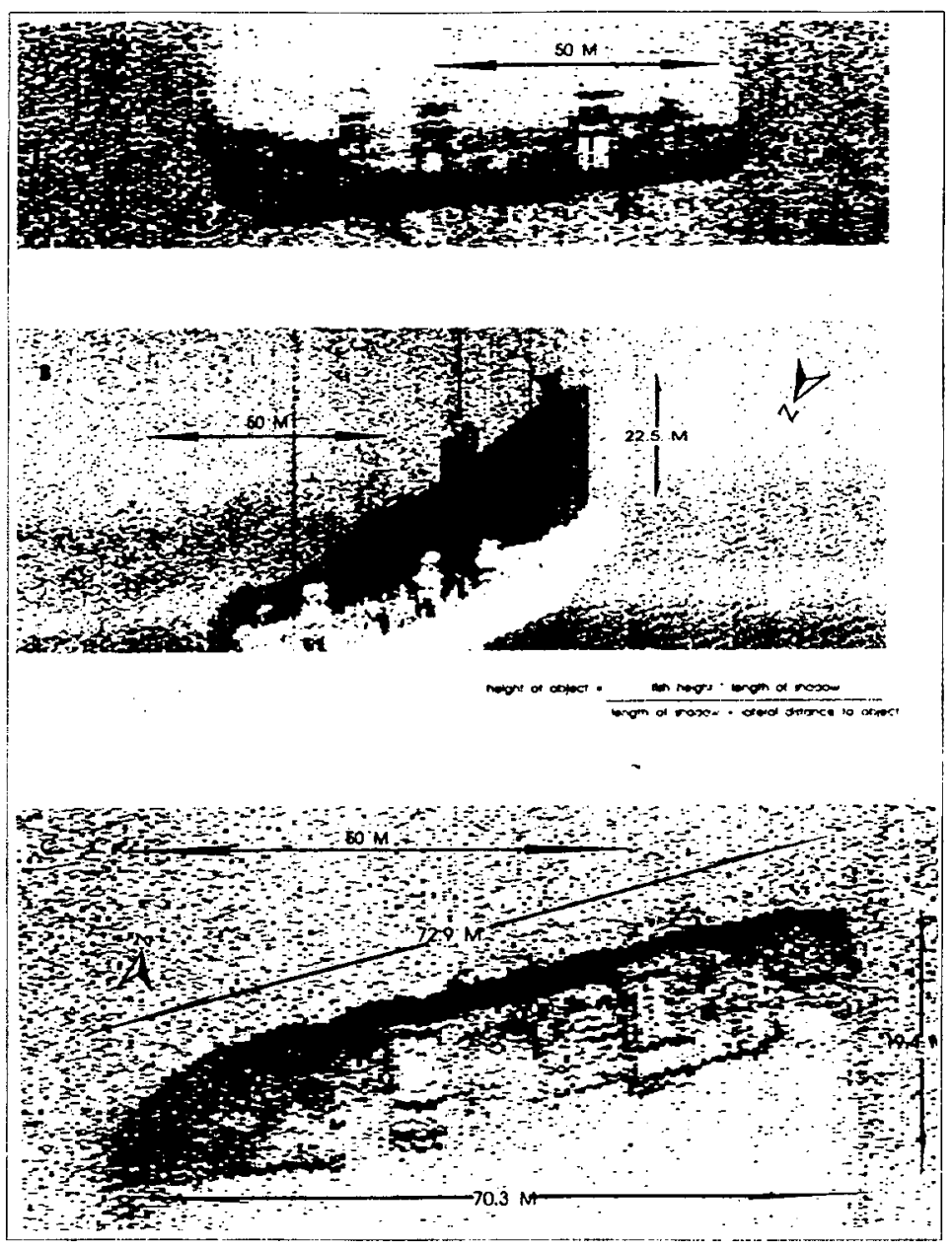

b)

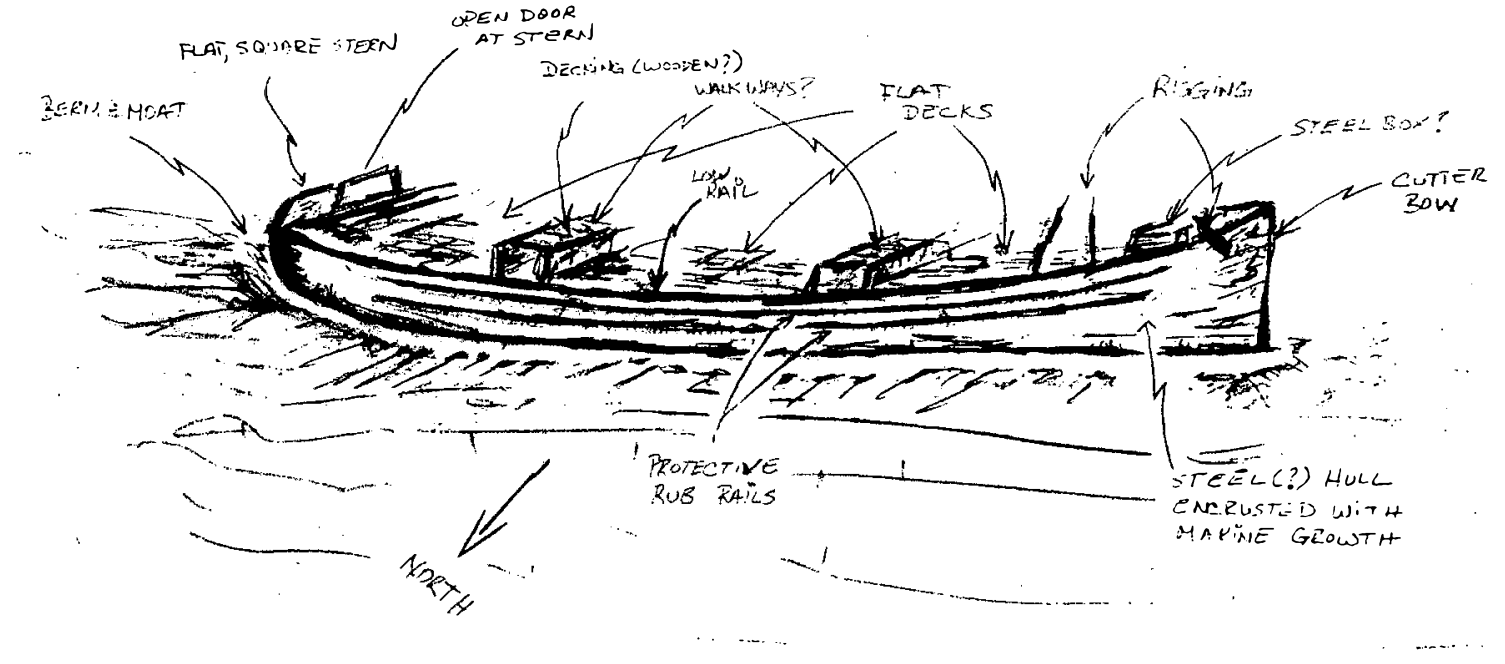

Fig. 15. a) Sidescan-sonar images of the shipwreck off the mouth of the Humber River. b) Sketch by G. Cameron based on observations from a submersible. 
3) Multibeam bathymetry and backscatter data reveal that the fiord's morphology is complex in detail; the sea floor has a range of fluid escape and current-formed features.

4) Sidewall valleys and associated toe deposits on the fiord floor are evidence of submarine slides that occurred in the lateglacial to early postglacial period.

5) The ancient submarine slide complexes are morphologically similar to the modern slide complex triggered by wharf building at Seal Head, although the triggering mechanism was obviously different.

6) Other human impacts include submarine slides of several types associated with road building, thick and extensive deposits of paper-plant waste on the sea floor off Corner Brook, dredge spoil off Corner Brook, and a large sunken vessel at the mouth of Humber River.

\section{ACKNOWLEDGEMENTS}

We thank the captains and crews of the research vessels Hart, Matthew and F.G. Creed for making the work possible. Gordon Cameron made observations of the shipwreck from a submersible based on the naval vessel HMCS Cormorant. Mobile Oil Ltd. of Calgary contributed towards the cost of a multibeam bathymetric survey in 1996. Bob Taylor and Russell Parrott internally reviewed the manuscript, and we are grateful for guidance by external reviewers David Piper and Ralph Stea. This is Geological Survey of Canada Contribution 200267.

\section{REFERENCES}

BARRIE, C.Q., \& PIPER, D.J.W. 1982. Late Quaternary marine geology of Makkovik Bay, Labrador. Geological Survey of Canada Paper 81-17, 37 p.

BATTERSON, M.J. 1999. Glacial history, sedimentology and palaeogeography of the Humber River basin, western Newfoundland. Ph.D. thesis. Department of Geography, Memorial University of Newfoundland, St. John's, Newfoundland, Canada.

Batterson, M.J., LiVERMAN, D.G.E. AND KIRBY, G.E. 1993. Glacial lake development and marine inundation, Deer Lake area, Newfoundland, Canada: topographically controlled deglaciation of an interior basin. Journal of Quaternary Science, 8, pp. 327 337.

Bøe, R., Hovland, M., Instanes, L., Rise, S., \& Vasshus, S. 2000 Submarine slide scars and mass movements in Karmsundet and Skudenesfjorden, southwestern Norway: morphology and evolution. Marine Geology, 167, pp.147-165.

BROOKES, I.A. 1974. Late-Wisconsinan glaciation of southwest Newfoundland with special reference to the Stephenville maparea. Geological Survey of Canada Paper 73-40, 31 p.

COURTNEY, R.C., \& SHAw, J. 2000. Multibeam bathymetry and acoustic reflectance imaging of the shelf seabed. Geoscience Canada, 27, pp. 31-42.

DYKE, A.S., \& PREST, V.K. 1987. Late Wisconsinan and Holocene retreat of the Laurentide Ice Sheet. Geological Survey of Canada, Map 1702A, scale 1:5,000,000.

FLooD, R.S. 1981. Distribution, morphology, and origin of sedimentary furrows in cohesive sediments, Southampton Water. Sedimentology, 28, pp. 511-529.

GRANT, D.R. 1987. Quaternary geology of Nova Scotia and Newfoundland: XII INQUA Congress, Ottawa, 1987; Excursion Guidebook A-3/C-3, National Research Council of Canada,
Ottawa, NRC 27525, 62 p.

GraNT, D.R. 1989a. Surficial geology, Sandy Lake - Bay of Islands, Newfoundland; Geological Survey of Canada, Map 1664A, scale 1:250 000 .

GrANT, D.R. 1989b. Quaternary geology of the Atlantic Appalachian region of Canada. Chapter 5 In Quaternary Geology of Canada and Greenland, Geological Survey of Canada, Geology of Canada, no. 1. Edited by R.J. Fulton, pp. 393-440.

Hicks, E.C., HilmaR, B., \& LiNDHOLM, C.D. 2000. Seismic activity, inferred crustal stresses and seismotectonics in the Rana region, Northern Norway. Quaternary Science Reviews, 19, pp. 14231436.

Josenhans, H.W., Zevenhuizen, J., \& MaClean, B. 1990. Preliminary seismostratigraphic interpretations from the Gulf of St. Lawrence. In Current Research Part B. Geological Survey of Canada, Paper 90-1B, pp. 59-75.

PARrotT, D.R., KoK-LENG, T., \& MACDONALD, A. 2000. Preliminary results of a multi-parameter survey of the Black Point offshore disposal site in Saint John Harbour, NB. In Proceedings, Coastal Zone Canada 2000, 18-20 September 2000, Saint John, New Brunswick.

RiCKETTS, M.J. 1987. Wild Cove Clay, Western Newfoundland: a review and recent work. In Current Research (1987), Newfoundland Department of Mines and Energy, Mineral Development Division, Report 87-1, pp. 57-62. St. John's.

SHAW, J., \& FORBES, D.L. 1995. The postglacial relative sea-level lowstand in Newfoundland. Canadian Journal, of Earth Sciences, 32, pp. 1308-1330.

Shaw, J., Forbes, D.L., Ceman J.A., Asprey, K.A., Beaver, D.E., WILE, B., Frobel, D., \& JODREY, F. 1995. Cruise Report 94 138: Marine geological surveys in Chedabucto and St. George's Bays, Nova Scotia, and Bay of Islands, Newfoundland. Geological Survey of Canada Open File 3230. 13 p. plus figures, tables, appendices.

Shaw, J., Christian, H.A., Beaver, D.E., \& AtKinson, A.S. 1997. Cruise Report 96165. A survey of Bay of Islands, Newfoundland. Unpublished Cruise Report, Geological Survey of Canada Atlantic.

Shaw, J., ForbeS, D.L., \& Edwardson, K.A. 1999a. Surficial sediments and placer gold on the inner shelf and coast of northeast Newfoundland. Geological Survey of Canada Bulletin 532, 104 p. \& maps.

Shaw, J., Christian, H.A., Dehler, S., \& Courtney, R.C. 1999b. Cruise Report 97060, CCGS Matthew. Ground-truthing of multibeam bathymetric data in western Newfoundland: Bonne Bay, Bay of Islands, Port au Port region, and St. George's Bay. Geological Survey of Canada Open File 3789, 26 p. plus figures.

Shaw, J., Grant, D.R., Guilbault, J.-P., Anderson, T.W., \& PARROTT, D.R. 2000. Submarine and onshore end moraines in southern Newfoundland: implications for the history of late Wisconsinan ice retreat. Boreas, 29, pp. 295-314.

SYVITSKI, J.P.M. 1989. On the deposition of sediment within glacierinfluenced fiords: oceanographic controls. Marine Geology, 85, pp. 301-329.

SYVITSKI, J.P.M. 1992. Marine Geology of Baie des Chaleurs. Géographie physique et Quaternaire, 46, pp. 331-348.

SYVITSKI, J.P.M., BURELL, D.C. \& SKEI, J.M. 1987. Fiords: Processes and Products. Springer-Verlag, New York, 379 p.

SYVITSKI, J.P.M., \& SHAW, J. 1995. Sedimentology and Geomorphology of Fiords. In Geomorphology and Sedimentology of Estuaries, Edited by G.M.E. Perillo, Elsevier, Amsterdam, pp. 113-178.

Editorial responsibility: Graham L. Williams 